\title{
SiM
}

\section{Innovative Partnership Formed to Restore the West Potrillos}

\author{
By Ray Lister, Phil Smith, Steven Torrez, and Stephen Baker
}

I n December 2010, a diverse group of partners that included sportsmen, ranchers, biologists, conservationists, and land managers met on the barren foothills of the West Potrillo Mountains southwest of Las Cruces, New Mexico, to celebrate the beginning of a large-scale land restoration project that was years in the making. Like many landscapes in southern New Mexico, the West Potrillos were once healthy grasslands but had suffered terribly from the encroachment of brush species such as creosotebush and mesquite. This collaborative partnership effort to improve the health of the West Potrillos highlights the success possible when partners, even those with significantly different ideas and objectives, work together to find common ground and develop strategies to realize a shared vision.

\section{A Widespread Problem and a Common Vision}

Early settlers wrote of the flowing grasslands across New Mexico. However, human influences on the landscape since the late 1800s have put a tremendous strain on the land, causing significant vegetation changes as brush species such as creosotebush and mesquite came to dominate the landscape over time, consuming precious resources and outcompeting native grasses. While some of these areas are considered to be ecologically stable, the habitat, with very little grass left, cannot support the rich and diverse flora and fauna it once did. Moreover, these degraded watersheds experience less infiltration, more runoff, and more soil erosion. These landscapes have been driven past thresholds, making recovery through managing resource uses next to impossible.

In 2005 the New Mexico Bureau of Land Management (BLM) launched the Restore New Mexico Initiative with the goal of restoring disturbed lands on a landscape scale through an ambitious partnership approach. What began as a concept has become a widely successful restoration and reclamation program involving numerous agencies, organizations, ranchers, and industry groups. So far, more than 1.8 million acres of impaired rangelands have been treated, beginning the transition to healthy ecological states.

The key goals of this aggressive partnership program are to restore wildlife habitat and improve water quality and overall watershed function. Landscape restoration in New Mexico has focused on controlling invasive brush species, improving riparian habitat, reducing woodland encroachment, and reclaiming abandoned oil and gas well pads, all of which improve watershed function and habitat for wildlife.

\section{Collaborative Perspectives}

In Doña Ana County, about 25 miles southwest of Las Cruces, New Mexico, lie the West Potrillo Mountains. The foothills are characteristic of fragile, degraded grasslands with a great potential to be restored. Most of this area is located within the West Potrillo Mountains Wilderness Study Area (Figs. 1 and 2) and has long been valued for its scenic, recreational, and wilderness qualities. Recreation opportunities include hiking, bird watching, photography, and hunting. It is here that the Las Cruces BLM District began formulating plans for the West Potrillo Mountain Grassland Restoration Project, an ambitious effort to treat 26,300 acres of impaired habitat.

With so many diverse interests, the BLM had to garner the cooperation and support of various partners in order to implement a landscape scale restoration project of this size. The first step was having everyone agree that this landscape is functioning below its natural potential and would not recover without human intervention. The next step was developing a collaborative

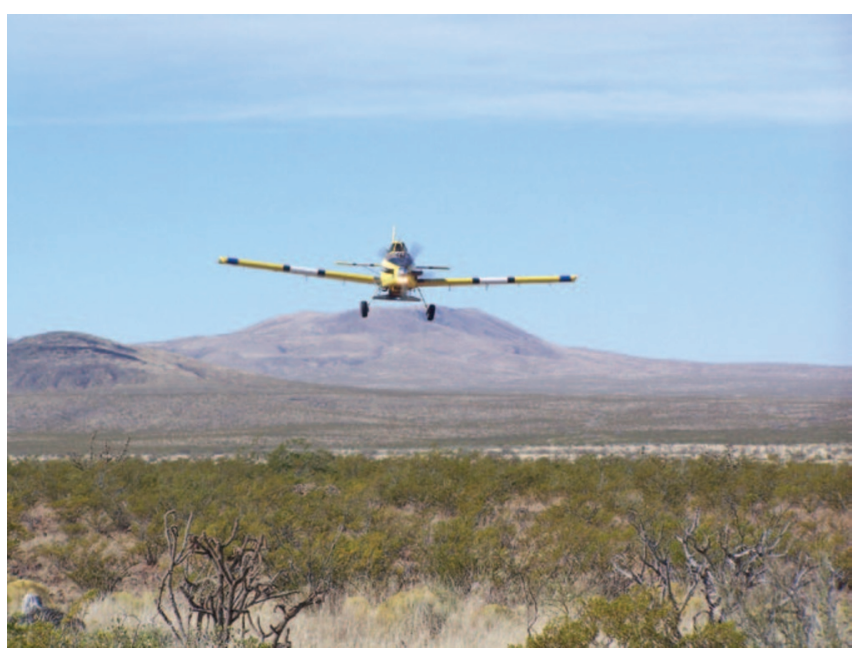

Airtractor Model 402 aircraft flying pelleted herbicide over West Potrillo Mountains Grassland Restoration Project. Photo courtesy of Amelia Underwood, Rangeland Management Specialist, BLM-LCDO. 


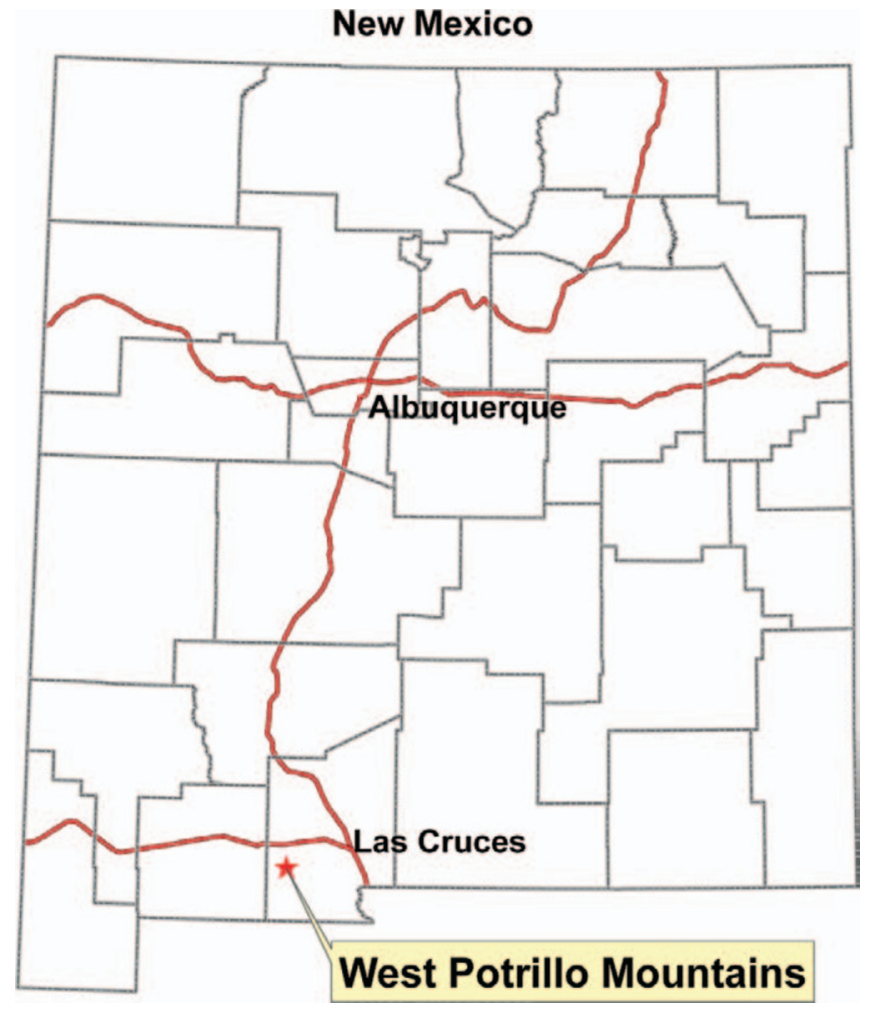

Figure 1. General location of West Potrillo Mountains Grassland Restoration Project.

strategy to restore these grasslands and achieve the common vision of a healthy watershed (Fig. 3).

"This area is a very special place to a lot of different people," explains Ray Lister, Supervisory Natural Resource Specialist for the BLM Las Cruces District. "Ranchers, sportsmen, and wilderness advocates all care deeply about the West Potrillos. Even though everyone approached this effort with their own perspective, we were able to come together and find a lot of common ground to develop a strategy to improve the health of the watershed and return the vegetative community to its natural potential."

When Nathan Small, Conservation Coordinator for the New Mexico Wilderness Alliance, first heard about the project, he was concerned by the use of herbicides but eventually signed on after visiting other treated sites and seeing firsthand the benefits of these treatments. "Because this project involves chemicals, this isn't an issue to be taken lightly," said Small. "But once we got out and saw the successes and potential of what was happening on the ground with these types of treatments, we got on board to support the effort. There are many diverse stakeholders involved, and we had the opportunity to restore native grasslands and help get the land back to a healthy state. It was a very positive situation."

Ken Leiting from the New Mexico Association of Conservation Districts had been involved in the funding of the project, working as an intermediary between the BLM and the local soil and water conservation districts. He saw this partnership as a unique collaborative effort between federal, state, and local agencies, as well as a wide variety of conservation and sportsmen groups. "This partnership effort went far beyond traditional partnerships," said Leiting. "The project out in the West Potrillos was about folks on the ground figuring out how to work together and then actually doing it to benefit the land."

"I've been coming out here since the 1950 s to hunt and camp, and over the years I've seen with my own eyes how much the land has declined," said Bud Starnes from the New Mexico Department of Agriculture. "There used to be so much more grass out here 50 years ago. I'm so glad to have been a part of these efforts to bring back the land to a healthy state."

"The historic change from grass to shrub-dominated landscapes has limited the capability of these habitats to support a diverse abundance and distribution of wildlife species," explained Steven Torrez, BLM Las Cruces District Wildlife Biologist. "Our goal was to restore the watershed, wildlife diversity, and naturalness to an extent that fire can play its historic role in limiting woody species within these sites."

The BLM regularly consults with the New Mexico Department of Game and Fish to identify priority areas for habitat restoration and participate in project design to ensure wildlife habitat objectives are addressed. Pat Mathis, a Wildlife Biologist with New Mexico Department of Game and Fish, was an early supporter of the project. "Without any intervention, this place would not get better on its own," said Mathis. "We were enthusiastic about this project and its potential benefit for wildlife."

Rancher Dudley Williams, the grazing permittee in this project area, spoke highly of the many partners coming together to accomplish this project. "I've always been an advocate of restoration, because the BLM and I can work together to find an option that works for all of us," Williams said. "We all saw the need to maintain healthy grasses, and not just for the ranching community, but for the health of the land and wildlife as well."

New Mexico Quail, Inc, and its predecessor, the Quail Unlimited Southwest Chapter, have worked with the BLM in the

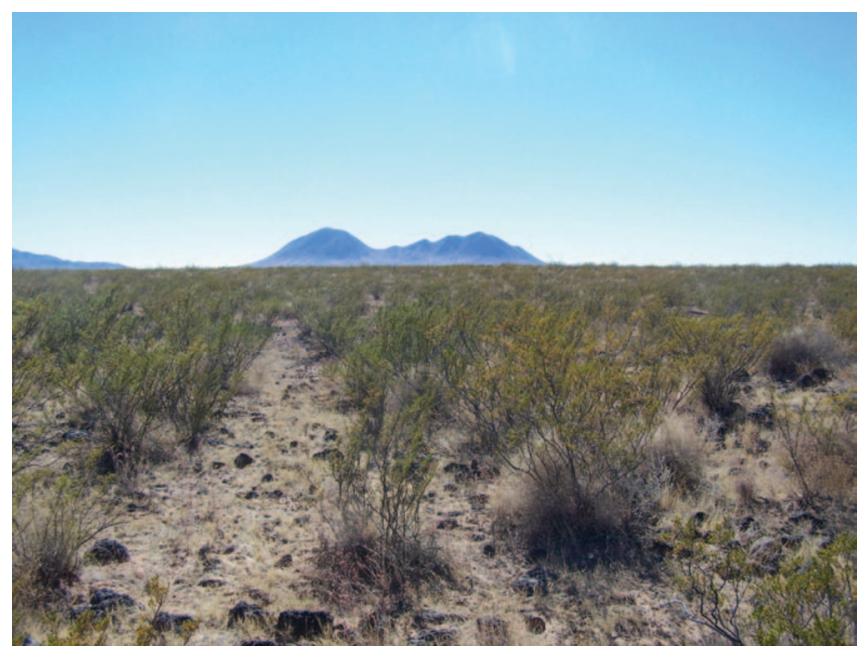

Figure 2. The West Potrillos foothills with Mount Riley in the background. Photo courtesy of Amelia Underwood, Rangeland Management Specialist, BLM-LCDO. 


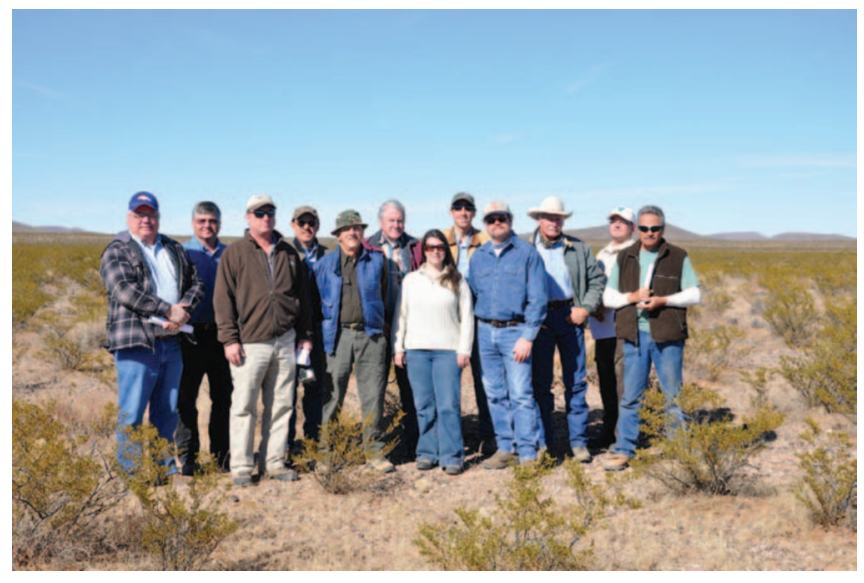

Figure 3. West Potrillo Mountains Grassland Restoration Project partners and supporters. Front row from left to right: Ken Leiting, New Mexico Association of Conservation Districts; Mark Spiess, New Mexico Quail, Inc; Bob Tafanelli, Mesilla Valley Audubon Society; Dara Parker, Senator Bingaman's Las Cruces office; Jim McCormick, BLM Las Cruces District Office; John Elwell, Williams Family Ranch. Back row: Pat Mathis, New Mexico Department of Game and Fish; Ray Lister, BLM Las Cruces District Office; Bud Starnes, New Mexico Department of Agriculture; Nathan Small, New Mexico Wilderness Alliance; Dudley Williams, Williams Family Ranch; Eric Ernst, BLM Las Cruces District Office. Photo courtesy of Stephen Baker, Public Affairs Specialist, BLM-NMSO.

past to improve quail habitat in southern New Mexico. The group provided the BLM with $\$ 34,000$ to help fund the West Potrillos project. "The sportsmen in our organization were excited to be part of such a worthwhile project," said John Moen, president of New Mexico Quail, Inc. "The habitat values in the West Potrillos will be increased a hundredfold. We have been waiting many years for a project like this in Doña Ana County."

Bob Tafanelli, representing the Mesilla Valley Audubon Society and New Mexico Wilderness Alliance, was approached by Lister for input from the wilderness community. Tafanelli had some initial concerns about the use of herbicides, monitoring, and grazing. After visiting other treatment sites and seeing the potential benefits of using herbicides to restore degraded landscapes, and being assured that scientific monitoring would be conducted and that no additional cattle will be grazed on the treatment sites, he endorsed the project. "Grassland bird species have been in decline for the past 50 years," said Tafanelli. "With this project we had the opportunity to restore crucial habitat for grassland birds and other wildlife."

\section{Project Implementation}

The West Potrillo Mountains Grassland Restoration Project objective was to return plant composition, distribution, and abundance within vegetative communities targeted for treatment to within the natural range of variability for the ecological sites that occur within the project area. Using state and transition models and ecological state mapping developed by the USDAARS Jornada Experimental Range (JER), gravelly range sites dominated by creosotebush were initially delineated. Field validation with an interdisciplinary team of resource specialists further refined target treatment areas (Fig. 4). Areas with high wildlife cover values (particularly swales and drainages) and areas determined to be degraded beyond expected response potential were buffered for nontreatment. This resulted in 26,300 acres targeted for herbicide treatment.

Initially the project was proposed to be accomplished in three phases, with approximately 12,000 acres in three different pastures to be treated annually, beginning in the fall of 2010. However, partnership funding, as well as additional BLM funds, were secured allowing for the entire acreage to be treated in year one. Due to the diverse stakeholder interest and support, the BLM was able to enlist the help of the New Mexico Association of Conservation Districts and the local Doña Ana Soil Water Conservation District to administer the contract and treat the entire acreage within the short window of opportunity for applying the herbicide.

"Once a brush species like creosotebush or mesquite overtakes a landscape and drives out the native grasses, it won't revert back to a healthy, balanced state on its own," explains Phil Smith, Rangeland Management Specialist for the BLM Las Cruces District. "Other removal techniques, like prescribed fire or mechanical removal, are ineffective or problematic, especially considering the scale of the problem. In the future, after the shrubs have been reduced and the grasses return, the land's healthy state can be maintained with natural or prescribed fire. Not only is the use of herbicides safe and effective, but it is the only viable option for restoring these shrub-invaded landscapes."

The herbicide used for treating creosotebush is a pelleted tebuthiuron (Spike 20P), a soil-activated herbicide that inhibits the photosynthesis of targeted brush species with little or no impact on grasses and forbs. Areas designated for treatment are programmed into the applicator plane's GPS-guided navigation system, which guarantees high accuracy when herbicides are applied. Sensitive habitats, such as riparian areas, drainages, or raptor nesting areas, are mapped as "leave-out" areas and not sprayed.

The particular project was located within the 127,473-acre West Potrillo Allotment, which supports yearlong grazing by

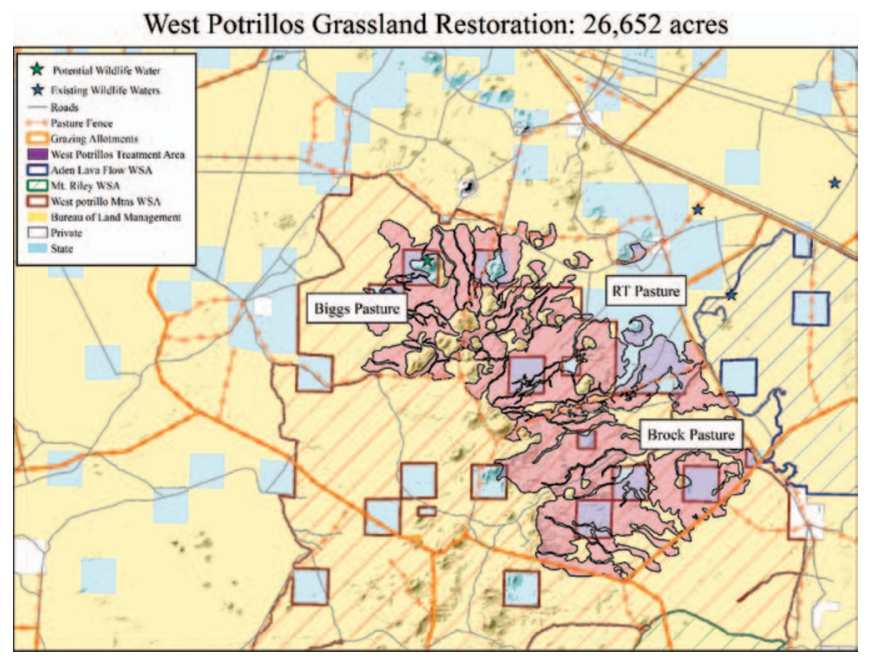

Figure 4. Project map with WSA boundaries showing treated area complexity. 
935 cattle. Many of the lands treated as part of the Restore New Mexico program allow cattle grazing. In order to participate in restoration projects, ranchers must agree to remove their cattle from the treated area for a minimum of two growing seasons following the treatment to allow the land to recover. Also, even though there is a much greater abundance of grass, additional cattle are not permitted following treatment. Nevertheless, most ranchers typically support treatments because of the overall benefits to their ranching operations from healthier rangelands

The livestock operator for this project, Dudley Williams, facilitated treatment of all three phases by adjusting his management to allow for the required growing season post-treatment deferment for 2 years following treatment in all three pastures. In addition, Williams agreed to provide the labor for the construction of additional fencing and water developments to improve management flexibility and facilitate the 2-year deferment within the three treated pastures.

In December 2010, airplanes applied tebuthiuron to significantly reduce the creosotebush and allow for native grasses to return. With sufficient time and precipitation, it is expected that the increase in herbaceous cover will reduce harmful runoff and erosion and significantly improve forage and habitat conditions for livestock and wildlife. "Depending on available moisture, it usually takes about 2 years for the native grasses to return after creosotebush is treated," Smith explained. "These results will not happen overnight, but the partners are confident this project will restore the West Potrillos to a healthy ecological condition, benefiting the land, wildlife, and many stakeholders who value this special place."

\section{Monitoring Progress}

In order to monitor progress in achieving common objectives, the BLM has collaborated with the JER to develop a posttreatment monitoring plan. In addition, the JER, in partnership with New Mexico State University, the University of Illinois, and the University of Oklahoma, has implemented a study to monitor responses by terrestrial plant and animal biodiversity to landscape-scale grassland restoration practices. This collaborative monitoring effort has helped design a practical monitoring scheme that can be used by land managers to assess both shortand long-term effects of shrub-control programs on the distribution, abundance, viability, and diversity of key vegetation and animal species. By developing a geospatial database of restoration outcomes, the study will also provide land managers with recommendations for targeting future treatment sites.

For the West Potrillos project, control study plots were identified during the design of the treatment. These areas were selected based on similar soil and ecological conditions to proposed treatment sites and were specifically identified to not be treated. Baseline (pre-treatment) vegetation data (line point and belt transects) were collected at treated and control plots within the first year following treatment. Pre-treatment baseline vegetative monitoring within the West Potrillos project has shown that shrub densities are much higher and grass densities are much lower than what is expected on the gravelly ecological site.
The monitoring plan calls for vegetation data to be collected again in the third year following treatment, and then every 5 years thereafter. We anticipate the shrub and grass densities will indicate a reversal in vegetative dominance and an improvement toward the historic state.

The West Potrillos project area is of particular interest to local sportsman for the scaled quail habitat it provides. Over the past few decades, New Mexico and many other southwestern states have experienced decreasing quail populations. Although scaled quail exhibit boom and bust population dynamics in response to changes in climate, particularly timing and variability of precipitation, the West Potrillos project presented an opportunity to evaluate the potential role habitat restoration may play in buffering quail, and other wildlife species, during periods of drought. The New Mexico Department of Game and Fish, together with the BLM and US Geological Survey Cooperative Fish \&Wildlife Research Unit located at New Mexico State University, are designing a study to measure the effects of shrub reduction treatments on scaled quail demography and seasonal habitat use. "The West Potrillos have historically been a hotspot for upland game bird hunters," said Torrez. "Our efforts to improve the habitat for quail and other grassland species will benefit from this study."

\section{Rewards of Success}

Accomplishing broad-scale landscape restoration is very difficult without strong partnerships and a shared vision. The success of the Restore New Mexico Initiative is rooted in the fundamental premise that even among a diverse group of partners - ranchers, environmentalists, industry groups, sportsmen, as well as other federal and state agencies - there is a lot that everyone has in common. When groups work together to realize a shared vision, remarkable things can happen, including the return of healthy, native grasslands, better habitat for wildlife, improved soil and water conditions, enhanced opportunities for recreationists and sportsmen, as well as better economic conditions for those whose livelihood depends on the land.

The West Potrillos project is but another example of how working cooperatively with partners to find common ground and develop strategies to bring about shared goals results in the ability to pool resources, knowledge, and skills to accomplish restoration projects on a landscape scale. This would not have been possible by working independently. Because goals and objectives were developed through a strong partnership, everyone involved is confident that the restoration efforts initiated in 2010 will result in these grasslands once again functioning within their natural potential.

In January 2012 the New Mexico Section of the Society for Range Management awarded the West Potrillo Grassland Restoration Project the 2011 Excellence in Range Management Award.

Authors are: Rangeland Management Specialist, psmith@blm.gov (Smith),Wildlife Biologist, storrez@blm.gov (Torrez), and Supervisory Natural Resource Specialist, rlister@blm.gov (Lister), BLM, Las Cruces, NM 88005, USA; and Public Affairs Specialist, BLM, Santa Fe, NM 87508, USA, sabaker@blm.gov (Baker). 